\begin{tabular}{|c|c|}
\hline 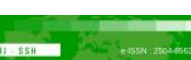 & Malaysian Journal of Social Sciences and Humanities (MJSSH) \\
\hline Malaysian Journal of & Volume 6, Issue 7, July 2021 \\
\hline (MJ-SSH) & e-ISSN : 2504-8562 \\
\hline & $\begin{array}{l}\text { Journal home page: } \\
\text { www.msocialsciences.com }\end{array}$ \\
\hline
\end{tabular}

\title{
Protecting Visually Impaired Peoples' Rights in Casting Votes in Malaysia
}

\author{
Rajini Kumar' ${ }^{1}$, Bavani Ramayah ${ }^{2}$ \\ ${ }^{1}$ Faculty of Creative Industries, University Tunku Abdul Rahman (UTAR), Kajang, Selangor, Malaysia \\ ${ }^{2}$ Faculty of Science and Engineering, University of Nottingham, Semenyih, Selangor, Malaysia \\ Correspondence: Rajini Kumar (rajini@utar.edu.my)
}

\begin{abstract}
Election is a process to choose an individual or a government by a citizen to manage a country. Freedom of expression is considered a natural right; one which belongs to everyone, by virtue of them being human. This freedom evident especially when one cast a vote in the General Election to choose the best candidate to represent him or her in Parliament. Therefore, there is doubt on such freedom of expression given to disable person especially people visually impairment. The objective of this research is to study about efficiency of Persons with Disabilities Act 2008 and Elections Act 1958 for protecting people with visual impairments' rights in casting votes. The outcome of this study will help to enhance the existing election process and Acts in order to protect the interests of people visually impairment in Malaysia.
\end{abstract}

Key words: freedom of expression, election, visual impairment, voting

\section{Introduction}

Malaysia has an huge responsibility to promote justice, respect for and observance of fundamental human rights since became a member of the United Nations on September 17, 1957 ${ }^{1}$. In fact, the principle of freedom of expression in Malaysia is enshrined in the Federal Constitution in Part II on Fundamental Liberties $^{2}$. During the past few years, the growth in political conscience and the growing number of Malaysian with a keen interest in democracy and human rights has raised the involvement of disable people in casting votes especially visually impaired people. Many challenges are identified in the process of casting votes among the visually impaired. Are visually impaired people's freedom of casting votes are protected? Firstly, this paper will explore the electoral system and process of election in Malaysia. Secondly, this paper will discuss about the effectiveness of Election Act (1958) and Persons with Disabilities Act 2008 in protecting visually impaired peoples' rights in casting votes.

\section{Electoral System in Malaysia}

An electoral system is is the set of rules that determine the process of electoral that identify the eligible individual to be the election candidate, to be elected by the voters during the election. The election system that is adopted by the Federation of Malaysia before its independence in 1957 is 'first past the post' (FPTP) system(Saravanamuttu, 2016).The electoral process in Malaysia begins when the prime minister

\footnotetext{
${ }^{1}$ United Nations Member States, 2006.

2 The Federal Constitution of Malaysia, 1957.
} 
dissolves parliament and calls for an election, an action that must occur within five years following the previous government. In the election, the eligible voters cast their votes ${ }^{3}$ to elect the member of Parliament or House of Representative at national level ${ }^{4}$ and to elect member of State Legislative Assembly at the states level ${ }^{5}$. The party that wins the majority of seats in the election will be announced as winners and will form the government. Relevant laws governing the electoral system in Malaysia are Election Offences Act 1954, Election Commission Act 1957, Elections Act 1958 and Elections (Conduct of Elections) Regulations $1981^{6}$.

\section{Election Process in Malaysia}

The entire election process is monitor by the Election Commission (EC) members. The EC members are officially appointed by the Yang di-Pertuan Agong (King) based on the advice of the Prime Minister. The election process begin with nomination where the nomination centers are setup in various locations by the Election Commission. This is to allow candidates to register themselves followed by campaigning. The period for campaigning allowed from the date of the nomination day until the polling day. The registered voters may cast their ballot in designated voting centers on the polling day. Usually, public holiday is declared when the polling day is held during weekdays to ensure maximum turnout of voters. Campaigning and advocacy are strictly not allowed within the voting centres ${ }^{7}$. Only the registered voters who are Malaysian citizens, 21 years old and above eligible to cast their votes ${ }^{8}$. After the time of voting ended, the vote counting will be held and upon the agreement of the competing candidates, the result of the election is broadcast officially through Television, Radio and etc.

\section{Electoral Process in Polling Station}

Electoral process in the polling station must be conducted effectively and efficiently to protect the interest of voters. Polling station will ensure that voters can cast their vote in secret and in a calm atmosphere. Presiding Officers are responsible for the conduct of the ballot in the polling station, with a sound knowledge of the voting procedures. Election commission has the responsibility to implement the process successfully. Figure 1 shows the flowchart of electoral process in polling centre. Upon arrival at the polling centre the voter must give his or her identification card to the election duty officer 1(Step 1). The duty officer will also read out the name with the identification number and cross out the name from the electoral list. This duty officer also will check the voter's hands for any marks. Next, the voter must proceed to the election duty officer 2 to have his or her finger painted with indelible ink (Step 2). The voter must be careful on where to place the fingers after the indelible ink is painted to avoid smudging the ballot paper, as this will cause the vote to be spoilt (invalid or cannot be counted) ${ }^{9}$.

Then, the voter must proceed to election duty officer 3 who will tear out, stamp, and issue the ballot papers (Step 3). The voter must make sure that there are no marks on the ballot papers. If there is, the voter should reject the ballot papers and ask for replacement. The voter has the right to ask for a new ballot paper. After receiving a clean ballot papers, the voter must proceed to the voting booth (Step 4). The voter must mark ' $\mathrm{X}$ ' on the ballot papers to indicate which candidate he or she chooses. Therefore, the voter must make sure that there is no mark outside of the ballot square, as it will spoil the vote. The voter must fold the ballot papers in half, walk to the ballot box and place the ballot papers into the appropriate box (Step 5). Two ballot boxes represent for the candidates who are competing for the State (Negeri) and Parliament (Parlimen) seats. After voting, the voter shall leave the voting centre (Step 6).

\footnotetext{
${ }^{3}$ Article 55(3), Federal Constitution of Malaysia 1957.

${ }^{4}$ Article 55(4), Federal Constitution of Malaysia 1957.

${ }^{5}$ Article 71, Federal Constitution of Malaysia 1957.

${ }^{6}$ Election Commission Malaysia.

${ }^{7}$ Election Commission Malaysia.

${ }^{8}$ Article 119(1)(a), Federal Constitution of Malaysia 1957.

${ }^{9}$ Election Commission Malaysia.
} 
Figure 1: Flowchart of Electoral Process in Polling Centre ${ }^{10}$

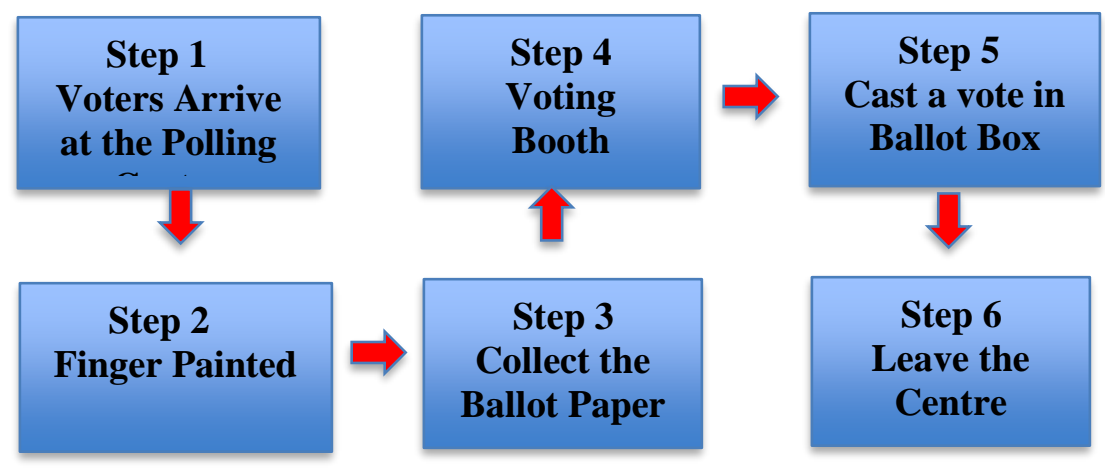

\section{Persons with Disabilities Act 2008}

The Persons with disabilities (PWDs) are now entitled to exercise their civil, political, social, economic and cultural rights on an equal basis with others ${ }^{11}$. It has been now 13 years since the Malaysian Persons with Disabilities Act 2008 was enacted. Whether this Act has the intended impact on protecting their rights have yet to be empirically ascertained. Malaysian government has implemented many policies to combat the problems among visually impaired people. The objective of Persons with Disabilities Act (2008) are: (1) accessibility to the physical, social, economic, and cultural environment; (2) accessibility to health, education, employment, information and communication; and (3) equal opportunities, protection and assistance in all circumstances and subject only to such limitations, restrictions and the protection of rights as provided by the Federal Constitution of Malaysia (1957). Prevailing regulations and compliance standards found in Malaysian legal policies, such as the PWDA (2008) (Part III of Act 685), which are aimed at facilitating the creation of accessibility to public facilities, amenities, services and equipment for PWDs. Such accessibility is the key for PWDs to fully and effectively participate and contribute to the well-being and diversity of the community and society.

\section{Elections Act 1958}

Elections in Malaysia are governed by the Federal Constitution, the state constitutions and the following acts and regulations such as the Election Commission Act (1957) ("ECA"), Elections Act 1958, Election Offences Act (1954), Elections (Conduct of Elections) Regulations (1981), Elections (Registration Of Electors) Regulations (2002) and Elections (Postal Voting) Regulations (2003) ${ }^{12}$. The Elections Act (1958) is a Malaysian law which is enacted to provide for the elections to the Dewan Rakyat (House of Representatives) and Dewan Undangan Negeri (State Legislative Assembly). The Elections Act (1958) consists of 6 Parts, (Part I: Preliminary, Part II: Supervision of Elections, Part III: Constituencies, Part IV: Registration of Electors, Part V: Conduct of Elections, and Part VI: Regulations ${ }^{13}$. The Act contain of 17 sections and no schedule (including 19 amendments) (Election Act, 1958). Apart from Elections Act (1958), there are others Acts which are related to the elections such as The Election Offences Act (1954) which is enacted to prevent electoral offences and corrupt and illegal practices at elections; to provide for the establishment of enforcement teams and for matters connected therewith; to provide for the appointment of election agents and to control election expenses; and to provide for election petitions (Election Offences Act, 1954). Elections (Conduct of Elections) Regulations (1981) is an act emphasized on the rules and regulations which governs the process of conducting election. This Act is about nomination papers, deposit by candidate, proceedings on nomination day, marking of limit of and keeping order at place of nomination, rejection of nomination papers, persons entitled to be present at

\footnotetext{
${ }^{10}$ Election Commission Malaysia.

${ }^{11}$ Persons with Disabilities Act 2008

${ }^{12}$ Election Commission of Malaysia.

${ }^{13}$ Election Act ,1958.
} 
nomination, and prohibition on withdrawal of candidature. Election Commission of Malaysia, abbreviated as EC, is a commission set up by virtue of Article 114 of the Federal Constitution for the purpose of ensuring fair and equitable operations in undertaking parliamentary and state elections in Malaysia. The EC is responsible and accountable in implementing the Acts to establish a fair election. For this paper only Election Act (1958) is analyzed in relation to the protection given of the said Act for the visually impaired people in casting votes.

\section{Discussion}

According to The United Nations Convention on the Rights of Persons with Disabilities (UNCRPD) persons with disabilities describes as those who have long-term physical, mental, intellectual or sensory impairments, which in interaction with various barriers may hinder their full and effective participation in society on an equal basis with others (United Nations 2011; International Foundation for Electoral Systems 2014b). Persons with Disabilities especially people with visual Impairment defined as "a reduction in the clarity with which a person can see objects" (Chou et.al, 2013). During the Asian Pacific Decade of Disabled Persons (1993-2002), the Malaysian government begins to pay serious attention to disability groups, which brought up various key issues affecting their daily lives. Few workshops were held to gather opinions and feedback on the draft from disability organizations (Bathmavathi, 2009). At last, the PWD Act (2008) is implemented on July 7, 2008. PWD Act 2008 is the first rights-based law for people with disabilities (PWD) in Malaysia (Loong, 2009). The objective of this act is to give equal rights and protections to the disabilities. The Act is a first rights-based legislation for people with disabilities in Malaysia. With the PWD act (2008) in place, the rights of Malaysians with visually impairment need to be protected especially the rights of casting votes without any challenges. Unfortunately, there is no section, clause or statement which explains on such protection. The act only underlines four general principles, namely on National Council for Persons with Disabilities, appointment of registrar general and registration of persons with disabilities, promotion and development of the quality of life and wellbeing of persons with disabilities and finally about general protection ${ }^{14}$. The act can be concluded as a promoting or campaigning tool to create awareness rather than protecting the visually impaired peoples' rights in casting votes.

In Malaysia, Election Commission has the mandate in implementing the fair election without any prejudice. Election Act (1958) empowered Election Commission in conducting and encouraging registered voters in casting their votes in the election. However, there is no any specific requirements in the Act that explained and protects the person with disability especially visual impaired people rights on casting votes. The Act emphasizes only on the procedures and processes in conducting election in Malaysia. Since there is no specific protection given to visually impaired people in casting their votes, associations such as Malaysian Association for the Blind (MAB) and National Council for the Blind Malaysia (NCBM) have proposed to the government to rectify the problem and to ensure people with disabilities are better able to exercise their right to vote. NCBM published a booklet with a title 'Guide to Helping and Interacting with Disable People' to ensure people with disabilities are better able to exercise their right to vote ${ }^{15}$.

Therefore, Election Commission has allowed the people with special needs to bring any individual whom they trust, to assist with the process of voting in the channel. With regards for allowing the matter to be carried out, the EC has amended the rule of 19 Elections Regulations (Conduct of Election) 1981 (Amendment) 2012 and was gazetted it on February 13, 2012. Prior to the amendment of this regulation, voters with special needs can bring a named relative who is a registered voter, or if there are no relatives nominated, the Presiding Officer shall mark the voter's ballot in the manner that is instructed by the voter ${ }^{16}$.

\footnotetext{
${ }^{14}$ Persons with Disabilities Act 2008

${ }^{15}$ National Council for the Blind Malaysia (NCBM).

${ }^{16}$ Election Commission of Malaysia.
} 
However, trust and privacy identified as two major issues for the visually impaired in casting their votes on polling day. They encountered these challenges during the last General Election of Malaysia 2018 (Ramayah et al., 2020). The electoral system is important because it exerts an essential and independent effect on electoral outcomes. There should no comprise in its process and freedom given to practice by the voters in casting their votes for their chosen candidate. Importantly, every vote is confidential, and no one shall assist a voter on his/her behalf in casting their votes. Bringing another individual to assist the visually impaired person to cast the vote is breach of confidentiality and invading the person's privacy. Such arrangement or procedure arranged defeats the purpose of democracy and against the freedom of speech and equality of the visually impaired person as enshrined in Federal Constitution. Article 10(1)(a) of the Federal Constitution of Malaysia explained that every citizen has the right to freedom of speech and Article 8 by clause (1) provides that all persons are equal before the law and entitled to its equal protection ${ }^{17}$. Hence both the privacy and trust of the visually impaired people are at risk.

\section{Conclusion}

One of the most critical ways that individuals can influence governmental decision-making is through voting. Voting is a formal expression of preference for a candidate for office or for a proposed resolution of an issue. In emphasizing the discussion above, it can be concluded that the Persons with Disabilities Act (2008), Elections Act (1958) and election process are not effective in protecting visually impaired person's freedom of expression in casting votes especially on the issue of privacy and trust. The Persons with Disabilities Act (2008) which is primarily enacted in protecting the rights of disable person in Malaysia unfortunately has failed. The Act more emphasizes on its accessibilities of public facilities rather than protecting the rights of the person especially on casting votes. Election Act (1958) complies more on procedural and processes of implementing election in the country. The rights of voting are focused on the Act generally without focusing on the person with disability especially visually impaired people. The Election Commission's initiatives on the accommodating the people with special needs in GE-13 should be welcomed, but there are issues of breach of trust and privacy that need consideration. For the improvement purpose the government should refer to the other countries Acts such as Ireland (Sorcha, 2018), Japan (Julian, 2017) and Australia (Stephanie, 2018) in amending the Persons with Disabilities Act (2008) and Elections Act (1958) in protecting visually impaired peoples' freedom of expression in casting votes. Focus attention to the process of election and method used in casting votes for the visually impaired is essential. This paper paved a way to alarm the government and the Election Commission on the important of protecting the trust and privacy for the visually impaired people.

\section{References}

Bathmavathi, K. (2009). A step Forwards: Finally, an Act for the disabled - but is it enough? Retrieved on June 29, 2009 from http://thestar.com.my/lifestyle/

Chou, C. F., Frances Cotch, M., Vitale, S., Zhang, X., Klein, R., Friedman, D. S., Klein, B. E. K. et al. (2013). Age-related eye diseases and visual impairment among U.S. adults. American Journal of Preventive Medicine, 45(1), 29-35. doi:10.1016/j.amepre.2013.02.018

International Foundation for Electoral Systems.(2014b). Equal Access: How to Include Persons with Disabilties in Elections and Political Processes. National Democratic Institute.

Julian,R. (2017). Japan's visually impaired voters benefit from unique project. Dw Akademie. Retrieved from http://www.dw.com/

Loong,S.L.(2009). Rights of disabled people to be taken care of. Retrieved on June 30, 2009 from http://iltcmalaysia.blogspot.com

Magdalene C.H. Ang. (2014). Do Persons with Disabilities Act (2008) and Organizational Culture Influence Managerial Intention to Hire Persons with Disabilities. The Perspective', Management Journal, 4l(2014) $81-89$.

\footnotetext{
${ }^{17}$ Federal Constitution of Malaysia.
} 
DOI: https://doi.org/10.47405/mjssh.v6i7.896

Ramayah, B. \& Sreedharam, R. K. (2020). Voting Experiences of Visual Impaired Citizens During Polling Day in Malaysia. Malaysian Journal of Social Sciences and Humanities (MJSSH), 5(7), pp. 1 - 6. doi: https://doi.org/10.47405/mjssh.v5i7.435.

Sorcha, P. (2018). Tactile ballot templates to facilitate visually impaired in voting. Retrieved October 24, 2018, from https://www.irishtimes.com/news

Stephanie,R. (2018). Vision-impaired voters to have access to electronic voting at state election. In Daily News. Retrieved from https://indaily.com.au/news/

United Nations.(2011).Thematic Study by the Office of the United Nations High Commissioner for Human Rights on Participation in Political and Public Life by Persons with Disabilities. The Office of the United Nations High Commissioner for Human Rights (OHCHR). 